Relations industrielles

Industrial Relations

\title{
Ten Pathways to Death and Disaster, By Michael Quinlan (2014) Leichhardt: The Federation Press, 272 pages. ISBN: 978-1-8628-7977-5
}

\section{Michel Pérusse}

Volume 71, numéro 3, été 2016

URI : https://id.erudit.org/iderudit/1037665ar

DOI : https://doi.org/10.7202/1037665ar

Aller au sommaire du numéro

Éditeur(s)

Département des relations industrielles de l’Université Laval

ISSN

0034-379X (imprimé)

1703-8138 (numérique)

Découvrir la revue

Citer ce compte rendu

Pérusse, M. (2016). Compte rendu de [Ten Pathways to Death and Disaster, By Michael Quinlan (2014) Leichhardt: The Federation Press, 272 pages. ISBN:

978-1-8628-7977-5]. Relations industrielles / Industrial Relations, 71(3), 568-569. https://doi.org/10.7202/1037665ar

Tous droits réservés (C Département des relations industrielles de l’Université Laval, 2016
Ce document est protégé par la loi sur le droit d'auteur. L'utilisation des services d’Érudit (y compris la reproduction) est assujettie à sa politique d'utilisation que vous pouvez consulter en ligne.

https://apropos.erudit.org/fr/usagers/politique-dutilisation/ 


\section{Recensions / Book Reviews}

\section{Ten Pathways to Death and Disaster}

By Michael Quinlan (2014) Leichhardt: The Federation Press, 272 pages.

ISBN: 978-1-8628-7977-5.

November 2010, Pike River Coal Mine, near Greymouth, New Zealand: an explosion occurs, killing 29 miners. As is the case with other multiple-fatality events, this accident attracted media attention for a couple of weeks. Then business went on as usual. The problem is that, according to the author, incidents like that occur on average every 11 or 12 years in New Zealand alone.

This small country is by no means exceptional in that respect. The book examines other events of that type in Australia, Canada, Great Britain and the United States. For instance, in May 1992, an explosion at the Westray mine in Nova Scotia killed 26 miners. The report of the Royal Commission led by Justice K. Peter Richard was understandably entitled The Westray Story: A Predictable Path to Disaster (interesting parallel with the title of Quinlan's book). This disaster led to Bill C-21 (also known as Bill C-45, as it was known before its adoption by the House of Commons), a modification of the Canadian Criminal Code which opened up the definition of criminal negligence to include negligence in cases of accidents resulting in bodily harm.

Nor is the problem new. A certain Karl Marx, author of a book entitled The Capital, wrote harsh passages about accidents and working conditions in coal mines (absence of safety measures, women's work, salary payment procedures, etc.). And that was in the middle of the nineteenth century!... Multiple-fatality accidents seem to confirm Marx's quote that "History repeats itself". The question is: Why?

According to his web site, "Michael Quinlan is a professor in the School of
Management and Director of the Industrial Relations Research Centre" at the University of New South Wales, Sydney, Australia. His major expertise (teaching and research) is the field of occupational health and safety (OHS) and risk, particularly aspects related to work organisation, management and regulation. He was hired by the New Zealand Department of Labour to write three reports in the wake of the Pike River disaster. This led him to expand his research to mining disasters in other comparable jurisdictions, and to disasters in other types of work places (factories, construction sites, refineries and oil rigs).

The first chapter contains mainly a historical review of multiple fatalities at work, and a selective review of the literature on workplace disasters. It lists a number of maritime and other transport tragedies ranging from 1800 to 1970, although these will not be analyzed in depth later on. The rest of the research, however, does include a number of the other workplace disasters identified between 1812 and 1970 .

The second chapter examines the regulatory frameworks in place in the five countries included in the study, with particular attention to mining laws and regulations. This chapter is somewhat technical, hence a bit more difficult to read. It does, however, shed some light on the debate between the need for "laws based entirely on prescriptive standards" (i.e. regulations which impose certain specifications for ventilation, equipment, machinery, safety procedures, and so on, for example) and the need for "process and performance standards" (i.e. obligations to perform certain actions, to put in place programs or systems, among other things). As regards mining safety, both types of legislations exist, with pros and cons, and some jurisdictions have shifted from one to the other (and back, sometimes) over time or following yet another disaster.

The third chapter is the one that identifies which aspects of history keep repeating themselves as regards mining disasters. It 
highlights 10 fundamental contributing factors which can be found in a significant number of multiple-fatality incidents. These factors are the heart of the matter. The author validates these findings by applying them to disasters in other types of workplaces in chapter four. They are related to:

1. Design, engineering, technical and maintenance failures;

2. Prior warning or causes for alarm ignored;

3. Failures in risk assessment;

4. Failures in management systems and hazard management plans;

5. Failures in auditing;

6. Economic pressures compromising safety;

7. Failures in regulatory oversight and inspection;

8. Workers and others expressing concerns prior to the incident;

9. Poor management-worker communication and trust;

10. Emergency and rescue resources and procedures.

It is noteworthy that only one is technical/operational (\#1), while two are disregards for warnings (\#2 and 8), two are related to the economic or regulatory environment of the organization (\#6 and 7) and four are due to flaws in the safety management system (\#3, 4, 5 and 10) or the management system in general (\#9). Perhaps it is the very nature of these factors that makes them repeat themselves again and again. This takes away the focus on worker unsafe behavior as the primary cause of accidents. As Quinlan says: "while unsafe practices in workplaces cannot be ignored, focusing on them in isolation from the social structures and interests that encourage them is misleading and ineffectual" (p. 169).

Albert Einstein defined insanity as "doing the same thing over and over again and expecting different results". If disasters are to be prevented, changes must be made about the 10 contributing factors identified herewith. That is why Chapters 5 and 6 address the question of "Learning from failure"; one proposes "some tools for action" and the other one draws "broader lessons" at social, governmental and corporate level.

The text at the back of the book qualifies it as "compelling and insightful". I agree.

\section{Michel Pérusse}

Associate professor

Université de Sherbrooke

\section{Les critiques de la gestion}

Par Jean Nizet et François Pichault (2015) Paris : La Découverte, Collection Repères, 128 pages. ISBN : 978-2-7071-8186-2.

La gestion des entreprises est régulièrement prise à partie par des auteurs critiques qui lui reprochent de nombreuses dérives et, entre autres choses, son point de vue essentiellement fonctionnaliste reposant sur une conception unitariste des intérêts des diverses parties en présence. L'ouvrage de Nizet et Pichault se donne comme mission de couvrir ces différentes recherches critiques de la gestion, aussi bien dans le monde anglo-saxon que francophone. Privilégiant les études de terrain aux avancées uniquement théoriques, les auteurs (qui sont au demeurant tous les deux détenteurs d'un doctorat en sociologie) ont pour ambition de mettre en exergue l'intérêt, mais aussi les limites, des recherches critiques sur la gestion.

Divisé en quatre chapitres d'environ vingt-cing pages chacun, ce petit livre est très agréable à lire. Illustré par plusieurs recherches critiques et empiriques récentes, il conduit le lecteur dans les dédales parfois obscurs de la réflexion critique sur la gestion. Le tout premier chapitre, intitulé «Les fondements des études critiques», présente tout à tour les apports du marxisme, de la tradition wébérienne, de l'École de Francfort, de Michel Foucault et du post- 